Dujic Dejan

DOI: 10.15170/DIKE.2021.05.01.04

PhD-hallgató

PTE ÁJK

\title{
A bonus ec diligens pater familias 20 . századi alakulása a német családjogban
}

\section{The Development of Bonus ec Diligens Pater Familias in the 20th Century German Family Law}

The process of women's emancipation in European legal culture can be divided into three major periods according to their defining issues and objectives. The findings of the following study refer to the period from the beginning of the 20th century to the present day, which is usually identified in the literature as the second wave, and then as the third wave from the 1990s onwards. The turning point between these two stages is the thirty years after 1950, when the social, personal and family legal status of women changed significantly in Europe. The demands of the third wave, the 'modern emancipation movement', which are still ongoing today, are of a different nature and are primarily sociological rather than legal nature. Although the topic of feminism is popular and has been dealt with in many ways in the Hungarian social science literature too, this study is nevertheless suppletory as I present the German marriage and family law reforms by means of the historical legal analysis, which will be supplemented in later studies by a comparison of Austrian and Hungarian law for the same period.

Keywords: marriage law, woman's rights, German Marriage Law Reform Acts, 'bousewife marriage model', 'principle of partnership', the modern family model

\section{Bevezetés}

A 20. századi női emancipációs törekvések eszmetörténeti háttere abból a felismerésből bontakozott ki, hogy a polgári modernizáció Európa szerte úgy ment végbe, hogy a természetjogból levezetett jogegyenlőségi elvet a nőkre nem, vagy csak formálisan vonatkoztatták. Ennek legszembetűnőbb példája a francia alkotmányozó nemzetgyúlés által elfogadott Emberi és Polgári Jogok Nyilatkozata (1789) ${ }^{1}$ volt, melyben a deklarált jogok tekintetében (a rabszolgaság elutasítása mellett) e jogoknak a nőkre való kiterjesztése is hiányzott, azaz az „embert” és a „nőt” - legalábbis társadalmi megítélésük alapján - elkülönítették egymástól. ${ }^{2}$ A társadalmat férfitársadalomnak

\footnotetext{
${ }^{1}$ HeRGER, Szakrális kontra szekuláris értékek a polgári modernizáció korában 33-44; KAJTÁR - HERGER, Egyetemes állam és jogtörténet 133-149.

2 A nők jogaiért vívott küzdelem kezdetei a felvilágosodás korára, a francia forradalom idejére vezethetők vissza. A liberté, egalité, fraternité jelszavakban megfogalmazódó eszmék a demokratikus társadalmi berendeződés alappilléreivé váltak, miközben egyre világosabbá vált, hogy ezeket az eszméket csak az emberiség felére, mégpedig a férfiakra hajlandó alkalmazni a társadalom. Olympe de Gouges, a női egyenjogúság francia harcosa 1791-ben írta meg A noôi jogok nyilatkozata címú munkáját, amelyben elítéli a patriarchális társadalmi berendezkedést, és azt követelte, hogy a nőket
} 
tekintették, és a különbségeket a társadalmat képző férfi-ember és a hozzá - a férfi akaratának és elképzelésének megfelelően - megalkotott nő között a biológiai tényszerűségben állapították meg (biológiai determinizmus). Az európai trend szerint a nőnek a 20. század második felére eső reformokig annyi volt a dolga, hogy igyekezzen a család belső egységét megszervezni, fenntartani, azaz a szerepe a társadalmi ideológiáktól és eszméktől hajtott világban arra korlátozódott, amit a „férfi állam”, a „társadalmi-ember” az igényeknek és szükségleteknek megfelelően a nőnek adott. „Igy tehát ha feltesszüle a kérdést: 'mi a nô?', a válasz a patriarchális társadalmi rend, avagy a férfiuralom jelentésmezejében keresendő: az, amivé a nő identitását a férfi alakitja: és olyanná alakítja, „, amilyennek látni és láttatni akarja. A nö olyanná lesz, amilyen sžerepmintákat, erkölcsi erényeket és normákat a férfi elöír neki.”’ A társadalmi egyensúly hiányának, valamint a diszfunkció és a diszharmonizáció egyik egyszerű okának az a nyelvi jelenség tekinthető, hogy az ember szó a férfi szinonimájává vált. ${ }^{4}$ Pierre Grimal francia történész is megjegyzi, „a történészele csak a férfiak történetéröl tudnak. Felhasználják az̧t a kettösséget, bogy sok nyelv ugyanazzal a névvel jelöli az emberi nem képviselöit, mint a bimnemüeket, és azon a címen, hogy az.»emberek «történetét mesélik el, a férjek, fivérek, fiúk és apák történetére szoritkoznak". ${ }^{2}$

Ezeknél a nyelvi (félre) fordításoknál nagyobb jelentősége volt a biológiai determinizmust valló szakemberek álláspontjának, melynek a mai napig számos híve van. Ez a felfogás a biológiai tényezőket veszi figyelembe a társadalom tagjai tekintetében, tehát azt a tényt, hogy a társadalom a nemiséget nézve bilaterális, azaz XX és XY kromoszómákból álló személyekre bomlik. Ez azt jelenti, hogy a biológiai férfi és a biológiai nő természeténél fogva különbözik, azaz a férfi születésétől fogva férfi, a nô pedig nô, és ez a tény nem változtatható meg. A biológiai determinizmus hívei - a kritika szerint a szocializáció kérdését figyelmen kívül hagyva - a nemek közötti (lélektani, pszichoszociális, viselkedésmintákra, társadalmi szerepekre és társadalmi státuszra vonatkozó) különbségeket a természet által meghatározottnak tekintik, melyet elsősorban a férfi és a nő emberi reprodukcióban betöltött eltérő funkciójára alapítanak. ${ }^{6}$

A biologizmus irányzatával szemben Simone de Beauvoir, francia egzisztencialista filozófus „A második nem” (Le Deuxième Sexe) címú írásában (1949, magyar fordításban 1969) azt állította, hogy „nönek nem sఇületünk, nơvé válunk”. Úgy vélte, hogy a születési nemtől eltérő, számos más elem, behatás is szerepet játszik a nemi identitás kialakulásában. A társadalmi nemiség irányzata (gendertan), amely a létrejöttét a feminista mozgalom második hullámának köszönheti, a 21. századra nyugat-európai és amerikai postmodern feminizmus alapfilozófiájává vált, összefonódva az abortusz szabadságának követelésével is, amelyért a házasságot visszataszitó konvenciónak tekintő, biszexuális Beawvoir az elsők között emelte fel a hangját. Gender-tanának az alapvető kérdése az volt, hogy „mitjelent az egy emberi lény sqámára, hogy nő?’ Bár explicit módon nem használta a társadalmi

ugyanazon jogok és lehetőségek illessék meg, mint férfitársaikat. Hangsúlyozta, hogy ,minden férfi és nő szabadnak és jogokban egyenlönek születik”, láttatva ezzel azt a tényt, hogy a francia nemzetgyülés által elfogadott Emberi és Polgári Jogok Nyilatkozatában megfogalmazottak csak a férfiakra vonatkoztak. Lásd DE GOUGES, Declaration of the Rights of Woman and the Female Citizen 49-51.

${ }^{3}$ HeLl, Egy testvér lesz minden ember 330.

${ }^{4}$ Ez a jelenség a magyar nyelvhasználatban falusi, tradicionális környezetben a hetven év feletti generációnál még ma is megfigyelhetô: az 'ember' kifejezés a 'férfi' szinonimája.

${ }^{5}$ GIRMAL, Introduction à l'histoire mondiale de la femme 7., idézi KÈRI: Tollam szivárványba mártom, passim.

${ }^{6}$ BOLEMANT - SZAPU, Bevezetés a gendertanulmányokba 10-13.

${ }^{7}$ LÉVY, Sartre százada 258-273. 
nem fogalmát, világosan utalt arra, hogy nőnek lenni nem csupán biológiai adottságot, hanem sokkal inkább társadalmi meghatározottságot (elhatározottságot) jelent. ${ }^{8}$

A 20. század második felére eső emancipációs reformok hátterében meghúzódó, ideológiai szempontból mélyen áthatott vita azonban elsősorban szociológiai karakterű volt és ma is az, hiszen a jogtudomány számára az már a német polgári törvénykönyv (BGB 1900) ${ }^{9}$ előkészítésének az időszakaszában, a 19. század utolsó másfél évtizedében sem volt kétséges, hogy a női jogegyenlősítés programja halaszthatatlan, ${ }^{10}$ ha akkor a megoldás még több szempontból váratott is magára.

\section{A patriarchális jogalkotás vagy modern jogegység?}

Az 1900. január 1-jén hatályba léptetett BGB szakmai sikeréhez, ami elsősorban a német térség magánjogának egységesítésében jelent meg, nem fér kétség. ${ }^{11}$ Kritikusai azonban úgy látják, hogy a „férfi-ember” német nemzetet egységesítette, és patriarchális törvénykezést valósított meg azzal, hogy a bonus ec dilligens pater familias (patria potestas) az egységes magánjogba is bekerült. ${ }^{12}$ Állításuk szerint a kódex a nőkrôl megfeledkezett, sőt visszalépést is jelentett ahhoz képest, amit a porosz természetjogi törvénykönyv, az ALR (Allgemeines Landrecht für die Preußischen Staaten 1794) nőkkel szembeni humánusa jelentett. ${ }^{13}$ A történeti jogi iskola germanista szemléletmódját tükröző BGB-t ehhez képest - a nők szempontjából - nem tartják pozitívnak: számukra csupán annyit hozott, hogy ezek után egységesen méltatlanul kezelték őket. Az új rendelkezések nem tették lehetôvé, hogy a német nő a családot és a házasságot érintő kérdésekben önálló döntést hozzon, mivel a patria potestas értelmében ez a jog a férjet illette (1354. \$1 a. bek. „A férfi jogosult az együttélés alatt az együttélést érintō valamennyi kérdésben döntést hozni. ’). ${ }^{14}$ A férj bármikor gyakorolhatta a felmondási jogot felesége munkáltatójával szemben, már amennyire egyáltalán megengedte a feleségének, hogy munkába álljon (1358. „„Ha egy nö személyes teljesités elvégzésére harmadikekal szemben kötelezettséget vállalt, így a férj a felmondási határidôk betartása nélkül bármikor felmondhatja ezen jogügyletet, ha kérelmére a gyámügyi bíróság erre feljogositja. A gyámügyi biróság akkkor köteles ęt a feljogositást megadni, ha kiderül, hogy a nö tevékenysége a

\footnotetext{
8 BEAUVOIR, A második nem, passim.

${ }^{9}$ Bürgerliches Gesetzbuch vom 18. August 1896, https://lexetius.com/BGB/1354,2.

${ }^{10}$ A BGB előkészítésének időszakában a német nőmozgalom észrevételiről és Gottlieb Planck reakcióiról lásd HERGER, A modern magyar házassági vagyonjog kialakulása és rendszere a német jogfejlődés tükrében 111-114, 140-145.

${ }^{11}$ A német egység létrejöttét (1871) követően a kodifikáció részeredményeit az ún. bizottsági tervezetben (Entwurf eines Bürgerlichen Gesetzbuches in der Fassung der ersten Beratung der I. Kommision, 1884-1887), illetve az I. tervezetben (Entwurf eines Bürgerlichen Gesetz̧buches für das Deutsche Reich. Erste Lesung, 1888) rendezték egységes szerkezetbe és tették közzé. A második bizottság munkájának eredményét, a II. tervezetet (Entwurf eines Bürgerlichen Gesetzbuches für das Deutsche Reich. Nach den Beschlüssen der Reichskommision. Zweite Lesung, 1894) és ennek revízióját (Entwurf eines Bürgerlichen Gesetz̧buches für das Deutsche Reich - Zweite Lesung, 1895), a Birodalmi Tanács javaslata követte. A Birodalmi Gyúlés a javaslat nem teljes ülésén történő tárgyalását 1896. február 3. és 6. között azzal zárta le, hogy egy újabb 21 tagú bizottságot bízott meg jelentés készítésével. Ezután a II. tervezetet (Entwurf eines Bürgerlichen Gesetzbuches für das Deutsche Reich, 1896) a Birodalmi Gyúlés teljes ülése 1986. július 1-jén a 288 képviselő közül 222 igen, 48 nem szavazattal és 18 képviselő tartózkodása mellett fogadta el. Miután a Birodalmi Tanács 1896. július 14-én megadta a hozzájárulását, a császár a BGB-t és annak bevezető törvényét ez év augusztus 24-én hirdette ki a Birodalmi Közlöny 21. számában.

12 WiegemanN, Der Hürdenlauf der Frauen im Recht 28-43.

13 A házas nő személyi és vagyoni jogi jogállásához a természetjogi kódexekben lásd HERGER, A modern magyar házassági vagyonjog kialakulása és rendszere a német jogfejlődés tükrében 82-87.

${ }^{14}$ „Dem Manne steht die Entscheidung in allen das gemeinschaftliche Eheleben betreffenden Angelegenheiten zu.”
} 
bázassági érdekeket tekintev hátrányos. A felmondási jog kizárt, ha a kötelezettségvállaláshoz a férj hozzájárult, vagy hozzájárulását a nö kérelmére a gyámügyi biróság pótolta. A gyámügyi biróság a hozzájárulást akkor pótolhatja, ha a férj betegsége vagy távolléte miatt akarályozva van a nyilatkozattételben és a késedelem veszéllyel jár vagy a hozzájárulás megtagadása joggal való visszaélést valósit meg. Amennyiben az életközösség megszünt, a férjet a felmondási jog nem illeti meg." $).{ }^{15}$ Dönthetett a lakhatással kapcsolatos valamennyi kérdésben (1354. \1b, bek. „Így különösen a lakhely és a lakás tekintetében.'), ${ }^{16}$ és a feleség köteles volt férje családnevét viselni (1355. \, „A nó, férje nevét viseli."). ${ }^{17}$ Kötelessége (és joga) volt az is, hogy a közös háztartást vezesse. Ez a szorgos és jó feleség, illetve anya nem csak a háztartásban dolgozott, hanem férje munkavégzésében is tevékenykedett annak megfelelően, hogy milyen körülmények között éltek (1356. „A nö ... jogosult és köteles a házvezetés elvégzésére. A házimunka valamint a férjének ügyletei tekintetében tevékenységre akkor kötelezett, ha azokra a körülményekre tekintettel, amelyeket a házastársak. házasságuk alatt köżtük rendszerint kialakitottak ę̧t szokványossá teszik.."). ${ }^{18}$ A törvényes vagyonjogi rendszert a férji vagyonigazgatási közösség (Verwaltungs-gemeinschaft) képezte, mely szerint a vagyonelkülönítés elve érvényesült a rendszer fennállása alatt, de a női vagyont a férj kezelte, azaz a nő arról önmaga nem rendelkezhetett (1363. \, A nö vagyona a házasság megkötésével férjének rendelkezése és haszonélvezete alá esik.."). ${ }^{19}$

A házas nő személyi és vagyoni jogállását érintő korlátozások egészen 1953-ig továbbéltek azzal, hogy a nő helyzetét, elsősorban a nő családon belüli kötelezettségeit a „Harmadik Birodalom” családpolitikája és családjogi jogalkotása még inkább megszigorította. A BGB családjogát ért kritikák ellenére is megállapítható, hogy a kódex átlátható, koherens szabályrendszert teremtett, és mintául szolgált nem csak Európában (ZGB 1912, OPTK novellák, magyar magánjogi törvényjavaslat 1928), hanem számos tengeren túli államban is, és a német egység helyreállítását követően 1990 őszétől a „régi-új” BGB ismét az egység egyik jeleként érvényesül. Legtöbb módosítás a BGB eredeti szövegén a hatályba lépése óta eltelt százhúsz évben kétségen kívül a családjog területét érintette.

\section{A női jogok biztosítása a Weimari Köztársaságban}

A legfontosabb változások, melyek a nőket személyi jogi és vagyonjogi szempontból is egyenlősítették, azaz a társadalom teljes jogú tagjává tették Németországban, 1918. november 12. után történt. A német feminista mozgalom fellépése a női jogokért és a nők társadalmi megítélésének és elismerésének javulásáért nem egy egyenesvonalú és egyenletes fejlődés volt,

\footnotetext{
15 „Hat sich die Frau einem Dritten gegenüber zu einer von ibr in Person zu bewirkenden Leistung verpflicbtet, so kann der Mann das Rechtsverbältnis obne Einhaltung einer Kündigungsfrist kündigen, wenn er auf seinen Antrag von dem Vormundschaftsgerichte dazu ermächtigt worden ist. Das Vormundschaftsgericht hat die Ermächtigung zu ertheilen, wenn sich ergiebt, daß die Thätigkeit der Fran die ehelichen Interessen beeinträchtigt. Das Kündigungsrecht ist ausgeschlossen, wenn der Mann der Verpflichtung zugestimmt hat oder seine Zustimmung auf Antrag der Frau durch das Vormundschaftsgericht ersetzt worden ist. Das Vormundschaftsgericht kann die Zustimmung ersetzen, wenn der Mann durch Krankheit oder durch Abwesenheit an der Abgabe einer Erklärung verbindert und mit dem Aufschube Gefahr verbunden ist oder wenn sich die Verweigerung der Zustimmung als Mißßbrauch seines Rechtes darstellt. Solange die häusliche Gemeinschaft aufgehoben ist, steht das Kündigungsrecht dem Manne nicht zu. "

${ }^{16}$ „... er bestimmt insbesondere Wobnort und Wobnung."

17 „Die Frau erbält den Familiennamen des Mannes.”

18 „Die Frau ist ... berechtigt und verpflichtet, das gemeinschaftliche Hauswesen zu leiten. Zu Arbeiten im Hauswesen und dem Geschäfte des Mannes ist die Frau verpflichtet, soweit eine solche Tätigkeit nach den Verbältnissen, in denen die Ehegatten leben, üblich ist."

19 „Das Vermögen der Frau wird durch die Eheschließung der Verwaltung und Nutznießung des Mannes unterworfen.” Lásd bővebben HERGER, A modern magyar házassági vagyonjog kialakulása és rendszere a német jogfejlődés tükrében 133-140.
} 
hanem többször szembe kellett nézni azzal is, hogy a már megszerzett jogokat vagy elveszítik, vagy ha formálisan nem is veszítették el, az igazságszolgáltatásban és a társadalmi együttélés más területein megszorították őket. Az elmúlt mintegy száz év tekintetében elkülöníthető ebből a szempontból a birodalmi választójogi törvénytől (Reichswablgesetø) a II. világháború kitöréséig tartó időszak, a II. világháború alatti időszak, a stagnálás korszaka, valamint a II. világháború utáni fellendülés időszaka, amely az 1950-es évektől napjainkig pozitív értelemben egyfajta folytonosságot mutat.

Nem tartozik a családjog területéhez, közvetett hatása miatt mégis kiemelendő, hogy 1918. november 12. azért jelentett fordulópontot a német nôk számára, mert a birodalmi törvényhozás ekkor kezdte meg a tárgyalásokat a nők aktív és passzív választójogának bevezetéséről, és ennek megfelelően a korábbi törvény módosításáról. Ennek következtében relatív gyorsan, 1918. november 30-án lépett hatályba a „Választási rendelet az alkotmányozó német nemzetgyűlés számára" (Verordnung über die Wablen zur verfassunggebenden deutschen Nationalversammlung), melyet a szakirodalom és a korabeli politikai közélet is birodalmi választójogi törvénynek nevezett. ${ }^{20}$ Ennek 2. \-a szerint „Választásra jogosult minden német férfi és nö, akile a választások napján 20. életévïket

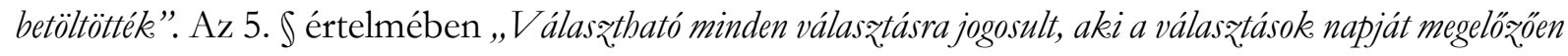
legalább egy éve német. ${ }^{21}$ A törvény 24 . \-a az alkotmányozó nemzetgyűlés megválasztásának napját 1919. február 16-re tűzte ki, ami többszöri módosítások után végül 1919. január 19. lett. ${ }^{22}$ Bár a nők választójogát nem érintette, fontos megemlíteni, hogy az 1918. november 30-án érvénybe lépett törvényerejű rendeletet ${ }^{23}$ ezt követően mintegy nyolc alkalommal módosult, mire végleges formáját új, rövidített elnevezéssel 1920. április 27-én elnyerte.

A reformtörvényt követő elsô választásokat tehát 1919. január 16-án tartották meg. Háromszáz nő jelöltette magát a német nemzetgyűlésbe (Deutsche Nationalversamlung), és közülük a négyszázhuszonhárom képviselői helyre harminchét női képviselőt választottak meg. Ez a siker alapvetően a marxista Clara Zetkin vezetésével múködő német radikális nőmozgalomnak, a Zetkin által alapított, illetve 1892 és 1917 között ${ }^{24}$ szerkesztett Die Gleichheit címú folyóirat hatásának, valamint a korabeli SPD (Sozialdemokratische Parteil Deutschland /Német Szociáldemokrata Párt) vezetésének volt köszönhető. ${ }^{25}$ Zetkin, bár meghatározó tagja volt az SPD-nek, 1917-ben a független USPD-hez, illetve annak szélsőbaloldali csoportosulásához (Spartakusbund) csatlakozott. Az ebből a csoportból 1919-ben létrehozott kommunista pártot (KPD) 1920 és 1933 között képviselte a birodalmi gyúlésben. Személye azért emelhető ki a nôi választójogért felszólaló német politikusok közül, mert beszédei és írásai, többek között a Leninnel 1920-ban a nőkérdésről készített interjú, ${ }^{26}$ ráirányítják a figyelmet a nyugati baloldali radikális feminizmus és a marxista-leninista

\footnotetext{
${ }^{20}$ http://www.documentarchiv.de/wr/1918/reichswahlgesetz.html\#fn01 (2018. 11. 30-i állapot).

${ }^{21}$ „(...) Wablberechtigt sind alle deutschen Männer und Frauen, die am Wabltag das 20. Lebensjabr vollendet haben”. „Wäblbar sind alle Wablberechtigten, die am Wabltag seit mindestens einem Jabre Deutsche sind".

22 http://www.documentarchiv.de/wr/1920/reichswahlgesetz_1920.html (1920. április 27-i állapot).

23 26. „Ennek a rendeletnek törvényereje van és kibirdetésének napjän lép hatályba.” A kihirdetés napja 1918. november 30. volt.

${ }^{24}$ ZETKIN, Abschied von der Gleichheit, https://www.marxists.org/deutsch/archiv/zetkin/1917/06/abschied.htm.

${ }^{25}$ STORM, 90 Jahre Frauenwahlrecht, Landeszentrale für Politische Bildung Reinland-Pfalz, https://www.politischebildung.rlp.de/fileadmin/download_neu/Frauenwahlrecht.pdf.

${ }^{26}$ ZETKIN, Lenin on the Women's Question, https://www.marxists.org/archive/zetkin/1920/lenin/zetkin1.htm.
} 
eszmerendszer kapcsolatára és a polgári nőmozgalom elutasítására, melyben - ha céljaik részlegesen azonosak is voltak - Zetkin elsősorban a munkásmozgalmat megosztó erôt látta. A polgári nőmozgalom és a baloldali radikális feminizmus kapcsolatát a német jogfejlődésben külön tanulmányban kívánom bemutatni.

A választójoghoz hasonlóan a nőkre vonatkozó munkajogi szabályok is közvetett hatást gyakoroltak a családjogi reformok iránti igényre. A pihenőidőre, a szabadnapokra, a munkaidő maximumra, az anyaság védelmére és a szociális jogokra vonatkozó előírások azonban már a 19. század utolsó harmadában megjelentek, elsőként az anyaság védelmének (Mutterschuta) megteremtésével nem sokkal a német egység létrejötte után (1878). Ezt 1882-ben az első Nố és Leány Társadalombiztositás kialakítása követte, majd 1891-ben az úgynevezett Munkásnővédelmi Törvény (Arbeiterinenschutżgesetz) lépett hatályba. A nőoktatás kérdésére azonban csak a századfordulót követően helyeződött hangsúly: 1901-ig nem iratkozhattak be nők az egyetemekre és a főiskolákra; a korabeli férfitársadalomnak nem volt szüksége arra, hogy a nő „túl okos és müvelt” legyen. Az első szövetségi tagállam, amely a nők felsőfokú képzéseken való részvételét 1901 után a miniszterelnök és a miniszterek támogatásával lehetővé tette, az akkori Baden volt. ${ }^{27}$ Szintén itt, Mannheim városában az akkori Handelshochschule Mannheim-ban, a mai nevén Universität Mannheimban, a Mannheimi Kereskedelmi Főiskola, majd Mannheimi Tudományegyetem oktatói karába nevezték ki az első nôi óraadót, Elisabeth Altmann-Gotheinert-et. ${ }^{28}$ Ennek köszönhetően 1913 ra Németországban egyetemi és főiskolai tanulmányokat folytató nők száma közel négyezer, az összes, felsőfokú tanulmányokat folytató diákok majd 4,5\%-a lett. 1922-ben először Marianne Weber-t, a német Nemzetgyưlésben elsőként felszólaló női képviselőt nevezték ki díszdoktorrá, majd 1923-ban Prof. Dr. Margarete von Wrangel lett az elsőként kinevezett „rendes” professzor a Hohenheimi Főiskolán. ${ }^{29}$

Ez a pozitív tendencia, legalábbis, ami a nők gazdasági, tudományos és munkajogi helyzetét illeti, 1933-ig maradt meg. A reformok azonban nem terjedtek ki a nő családjogi jogállására. Itt továbbra is a patriarchális férfi hatalom dominált, azaz a férj volt a római jogból megörökölt, de a germán jogi hagyatékkal is indokolható bonus ec diligens pater familias egyedüli és teljes letéteményese.

\section{1933-1945: a stagnálás évei}

A nemzetszocializmus előretörésével 1933 után a női jogok területén erőteljes visszarendeződés valósult meg. A náci rezsim fennállása alatt (1933-1945) nő „anya és gyermekegyártó, a férfit kisegitó társadalmi elem ${ }^{\not 30}$ lett. A totális állam mindennemű politikai és tudományos területről kizárta a nőket. Nem volt elvárás, hogy a nő okos legyen, elégséges volt, ha szép és termékeny. A rendszer a nőt nem látta többnek az árja faj fenntartásához szükséges „reprodukciós kelléknél”. ${ }^{1}$ A női szerep

\footnotetext{
${ }_{27}$ STORM, 90 Jahre Frauenwahlrecht, Landeszentrale für Politische Bildung Reinland-Pfalz, https://www.politischebildung.rlp.de/fileadmin/download_neu/Frauenwahlrecht.pdf.

${ }_{28}^{28}$ Di CROCE, Historische Ereignisse, https://www.frauenwahlrecht-bw.de/damals-heute/zeitstrahl/.

${ }^{29}$ Di CROCE, Historische Ereignisse, https://www.frauenwahlrecht-bw.de/damals-heute/zeitstrahl/.

${ }^{30}$ Részlet Joseph Goebbels propaganda miniszter beszédéből a „Die Frau“ címú kiállítás megnyitóján (Berlin, 1933. március 19.). Közli: HeLLWIG, Weg zur Gleichberechtigung 254.

${ }^{31}$ Részlet Joseph Goebbels propaganda miniszter beszédéből a „Die Frau“ című kiállítás megnyitóján (Berlin, 1933. március 19.). Közli: HeLLWIG, Weg zur Gleichberechtigung 254.
} 
lényegét a szülésben és a gyermekek felnevelésében látták. A nő dolga a család ellátása és az árja gyermekek felnevelése volt, a férfi, mint a társadalom egyetlen lényeges tagja pedig a politika, a honvédelem és a keresőtevékenység egyedüli jogosultja: „Nem maradhat kimondatlan, hogy dolgok, amelyek a férfit illetik meg a férfinál is kell, hogy megmaradjanak. Ehhez. tarozile a politika és egy ország bonvédelmi képessége - a nôi emancipáció egy csak a zsidó értelmiség által kitalált szó. Nem tartjuk helyesnek, ba az asszony a férfiak világába behatol, belyesnek tartjuk viszont, ba ez a két világ egymástól elkeülönülve megmarad." ${ }^{32}$ Egy tisztavérü német nő nem végeztetett vagy végezhetett abortuszt, kivéve, ha nyilvánvaló volt, hogy a gyermek valamilyen fogyatékossággal születne. A rendszernek tehát nem a magzatelhajtás jelenségével volt problémája, nem a méhmagzat életét védte, hanem az árja gyermekek születését sürgette. A propaganda a „tisztavérű” társadalmat éltette, minden ezzel ellentétes magatartás, ideológiai nézet és vélemény már csírájában elfojtásra került. Igaz viszont az is, hogy aki ennek a populista rezsimnek hű híve, jó állampolgára volt, a nők esetében három vagy több gyermeket szült, kitüntetett szerepet és átlag feletti szociális biztonságot kapott. ${ }^{33}$

Bár von Hindenburg birodalmi elnök haláláig (1934. augusztus 2.) Adolf Hitler nemzetiszocialista kormánya még némi visszafogottságot tanúsított a nőkérdés tekintetében, ettől kezdve azonban a nőt csak a férfi segédjének, „munkásnake és nemi elvtársnak” tekintették. A nők elsődleges szerepe a gyermekszülés és -nevelés lett olyannyira, hogy a nő „termékenységének hajlandóságát” jogszabályi úton igyekeztek elősegíteni. 1933 elején bevezették a házasságkötési kölcsönt (Ehestandsdarlehen). ${ }^{34}$ Ennek a kölcsönnek az volt a szerepe, hogy ezzel a házasságok megkötését szorgalmazza, valamint az árja nô teherbeesési szándékát növelje, így hozzájárulva az árja faj fenntartásához és szaporodásához. Bár választási kampányukban ígértet tettek, hogy a nő munkát vállalhat és jövedelemmel rendelkezhet, a kölcsön tetemes összegének a jóváhagyásához szükség volt arra, hogy a nő lemondjon minden kereső tevékenységről, legkésőbb a teherbeesés időpontját követően. A visszafizetés mértéke gyermekenként 25\%-al csökkent, és négy gyermek után a német állam a kölcsönt elengedte. ${ }^{35}$ A propagandaminisztérium állásfoglalásában megtiltotta „tisztavérú ária nônek”” az abortuszt, ellenben állami kényszerrel is elvégezték az abortuszt és a meddôvé tételi műtéteket minden nem tisztavérû, a nemzetiszocialista identitást elutasító vagy bármilyen fogyatékosságban szenvedő nő esetén, mivel úgy vélték, hogy a fogyatékosság átszállhat a gyermekre.

A nők foglalkoztatásával és szerepével kapcsolatos addigi nézetek és anyagi támogatások, amelyeket azért juttatott a német állam a nőknek, hogy véletlenül se keveredjenek a férfiak munkásvilágába, az 1940-es évek elején megváltoztak, és új propaganda vette kezdetét. Kialakult egy új társadalmi réteg, és új szerephez jutottak a nők, függetlenül attól, hogy kívánták ezt vagy sem. Az új réteg ,a hazai front harcosai” elnevezéssel a nemzetszocialista nőiideál által megalkotott speciális „kényszertársadalom” volt: ide tartoztak azok a nők, akik a férfi munkaérő hiányában az 1940-es évektől kezdve olyan feladatokat láttak el, amelyek a német katonagazdaság múködését

\footnotetext{
32 „(...) aber es darf nicht ungesagt bleiben, dass Dinge, die dem Mann gebören, dem Mann auch verbleiben müssen. Und daఇu gehört die Politik und die Wehrhaftigkeit eines Volkes (...). (...) das Wort von der Frauenemanzipation ist ein nur vom jüdischen Intellek.t erfundenes Wort. Wir empfinden es nicht als richtig, wenn das Weib in die Welt des Mannes eindringt, sondern wir empfinden es als natürlich, wenn diese beiden Welten geschieden bleiben (....).” Részlet Joseph Goebbels propaganda miniszter beszédéből a „Die Frau"című kiállítás megnyitóján (Berlin, 1933. március 19.). Közli: HeLLWIG, Weg zur Gleichberechtigung 254.

33 HELLWIG, Weg zur Gleichberechtigung 254.

${ }_{34}$ ABRAM, Ehegesundheit - Überblick über die Entwicklungen anhand der Gesetzgebung im „Dritten Reich“ 3-18.

35 1. $\int$ 1b. bek., Reichsgesetzblatt 1933/1. 60.
} 
biztosították és fenntartották. 1942-től a „munkakerülő nőkeet” kényszerítették a munkavállalásra. Ekkor már az a család volt jogosult a fent említett állami kölcsönre, melynek nőtagjai munkába álltak, természetesen jóval kevesebb munkabérért, mint a férfi társaik. Ezzel egyidőben viszont ismét lehetôvé tették a nők számára a felsőfokú képzések igénybevételét, sőt egyenesen szorgalmazták azt. A háború utolsó éveiben a nők minden addigi jogaikat, amelyeket a 19. század végétől kiharcoltak maguknak, elveszítették: a nemzetszocialista kormány nem foglalkozott a munkaidô maximummal, a szabadsággal vagy az anyaság védelmével. A nők dolga a náci rezsim utolsó éveiben az volt, hogy legalább három-négy gyermeket neveljenek, és mellette tíz-tizenkét órás műszakokban végezzék el azt a munkát, amely a német állam fennmaradásához szükséges volt. ${ }^{36}$

\section{A nők jogai és társadalmi megítélése 1945 után}

A II. világháború utáni időszakban az elsődleges cél az volt, hogy a politikai és gazdasági stabilitás helyreálljon, ezért a nők gazdasági életben való részvételét nem hangsúlyozták. Megelégedtek az általános, ,férfiak és nơke egyenlök" alaptörvényi deklarációval anélkül, hogy bármilyen jogi garanciát biztosítottak volna a nők számára ahhoz, hogy ez az elv érvényre is jusson. A tényleges reformok csak a feminista mozgalmak újjáéledésével kezdődtek meg az 1960-as években. Az ezt megelőző reformkísérletek, mint az alaptörvényi szabályozás és az 1957. évi családjogi reform, nélkülözhetetlen előfutárai voltak a modern értelemben vett egyenjogúság megvalósításának.

A BGB negatív hatásainak, a fent említett ,jó és gondos családapa” teljhatalmának vonatkozásában elsóként a német Alaptörvény (GG) próbált gátat szabni, és ezzel a férj hatalmát a házas nő felett korlátozni. 1945-ben a GG születésénél a honatyák nem tartották szükségesnek azt, hogy a nemi jogegyenlőséget alaptörvényi szinten rögzítsék. Miután viszont az 1946-ban újraalakult német törvényhozásban a képviselők több mint 7\%-a nő volt, az alaptörvény anyjának is nevezett Elisabeth Selbert (SPD) képviselőnőnek, valamint a köré csoportosult képviselőknek köszönhetően a GG hatálybalépéséig (1949. május 23.) sikeresen kiharcolták azt, hogy a GG-be bekerüljön „a férfiak és a nök egyenlöék" mondat (3. cikkely 2 . bek.). ${ }^{37}$

\subsection{Az 1957. évi egyenjogúsági törvény}

A BGB családjogában a férji jogok túlsúlyának az 1957. június 18-i egyenjogúsági törvény ${ }^{38}$ kívánt véget vetni. Ennek szükségességét jól mutatják azon korabeli normák, melyek a nő kereseti és gazdasági lehetőségeit, valamint kötelmi jogi felelősségvállalását korlátozták, avagy egyenesen kizárták. Ilyenek voltak a BGB fent már idézett 1354., 1355., 1356., 1358., és 1363. szakaszai, illetve a középkori, germán gyökerű jogintézmény, az ún. kulcshatalom (Scblïsselgewalt) ${ }^{39}$ némileg modernizált formában történt megőrzése, melyet a BGB a következőképp rendezett: „A feleség jogosult arra, hogy a férj helyett a házastársi tevékenységi körébe tartozó ügyeket intézze, és képviselje ót. Azokat a

\footnotetext{
36 BetTElHeim, Die deutsche Wirtschaft unter dem Nationalsozialismus 230.

${ }^{37}$ Di CROCE, Historische Ereignisse, https://www.frauenwahlrecht-bw.de/damals-heute/zeitstrahl/.

38 Gesetz über die Gleichberechtigung von Mann und Frau auf dem Gebiet des bürgerlichen Rechts vom 18. 06. 1957 (GLEICHBERG), BGBL. I, 609.

${ }^{39}$ SCHWAB, Familienrecht 73-84.
} 
jogügyleteket, amelyeket e tevékenységi körébe tartozóan végez̧, úgy kell tekinteni, hogy azokat a férj nevében végezte, kivéve, ha a körülményekböl más következik. A férj korlátozhatja vagy kizárbatja a feleség e jogát. Ha a korlátozás vagy kizárás a fér jogával való visszaélésnek tünik, aẓt a biróság a feleség kérelmére visszavonhatja. (1357. \1. és 2. bek.).

Az 1950-es években feléledt német nőmozgalom rámutatott arra, hogy a GG egyenjogusági elvének érvényesítését a jogalkotó mindaddig semmilyen garanciális jogszabállyal nem biztosította. Ennek hatására a Szövetségi Tanácsban (Bundesrat) 1953. január 29-én a jogegyenlőség tényleges megteremtése és védelme érdekében terjesztettek elő egy jogszabálytervezetet, amely végül öt évvel később, 1958. június 1-jén lépett szövetségi törvényként hatályba. ${ }^{40}$ A törvény a BGB 1354. szakaszát a férj döntési jogáról és 1358. szakaszát a férj úgynevezett felmondási jogáról hatályon kívül helyezte, és több tekintetben újraszövegezését valósított meg. Az új 1356. \szerint „A feleség saját felelósségére vezeti a báztartást. A nönek joga van keresö tevékenységet folytatni, amennyiben ez. összeegyeztethető a házassági és családi kötelezettségeivel.” Az 1357. \ értelmében „A feleség jogosult arra, hogy a házastársi sajéráján belül a férj is hatállyal ü̊letet kössön. A férj jogosultja és egyben kötelezettje azoknak a jogügyleteknek, amelyeket a nô e tevékenységi körén belül vállal, kivéve, ha a körülmények másként nem rendelkeznek; ha a férj nem képes teljesiteni, a feleség is kötelezett adós. A férj korlátozhatja vagy kizárhatja a feleségnek a nevében történö ügyintézésre vonatkozó jogosultságát; ha a korlátozásra vagy kizárásra nincs alapos oka, a biróság a feleség kérelmére visszavonja ąt. A korlátozás vagy kizárás harmadik szuemélyekkel szemben csak az. 1412. szakasznak megfelelóen történhet."

A nemi jogegyenlőségről szóló törvény lényeges változásokat hozott a nők számára a házassági vagyonjogban is azzal, hogy a szerzeményi közösséget (Zugewinngemeinschaft) törvényes vagyonjogi rendszerként intézményesítette a BGB germanista férji vagyonigazgatási rendszere (Verwaltungsgemeinschaft) helyett, melyet az alkotmánybíróság 1953-ban nyilvánított alkotmányellenesnek a GG nemi jogegyenlőségről szóló szakasza alapján. Az 1363. 』 szerint „A bázastársak szerzeményi közösségben élnek, kivéve, ha bázassági szerzödésben másként állapodnak meg. A férj vagyona és a feleség vagyona nem válik a házastársak közös tulajdonává; ez vonatkozile a házastársak által a házasságkötés után szerzett vagyonra is. A bázastársak által a házasság alatti szerzeményeket azonban ki kell egyenliteni, ha a szerzeményi közösség megszünik." ${ }^{41} \mathrm{Ez}$ az úgynevezett szerzeményi kiegyenlítés (Zugewinnausgleich) a házasság alatt részben vagy egészben a házatartásban tevékenykedő, gyermekeket nevelő nő érdekét szolgálta és szolgálja, aki ilyen módon részesedik a kereső tevékenységet folytató férjnek abból a vagyonából, melyek a rendszer létrejötte és megszűnése között keletkeztek és a szerzeményi közösségből nincsenek kivonva. ${ }^{42}$

A reformnak köszönhetően a BGB mára három vagyonjogi rendszert kínál a német állampolgároknak: törvényes rendszerként a szerzeményi közösséget, valamint szerződéssel kiköthető rendszerként a vagyonelkülönítést (1414. \) és a vagyonközösséget (1415. 『). A

\footnotetext{
40 Stellungnahme des Bundesrates, Entwurf eines Gesetzes über die Gleichberechtigung von Mann und Frau auf dem Gebiete des bürgerlichen Rechts (2. Whalperiode 1953 am 29. Januar 1954/Drucksache 224), https://dserver.bundestag.de/btd/02/002/0200224.pdf.

${ }^{41}$ „Die Ehegatten leben im Güterstand der Zugewinngemeinschaft, wenn sie nicht durch Ehevertrag etwas anderes vereinbaren. Das jeweilige Vermögen der Ehegatten wird nicht deren gemeinschaftliches Vermögen; dies gilt auch für Vermögen, das ein Ehegatte nach der Eheschließung erwirbt. Der Zugewinn, den die Ehegatten in der Ehe erzielen, wird jedoch ausgeglichen, wenn die Zugewinngemeinschaft endet."

${ }^{42}$ HeRGER, A modern magyar házassági vagyonjog kialakulása és rendszere a német jogfejlődés tükrében 386-388.
} 
házastársak magánautonómiáját biztosítva a jogszabály lehetôvé teszi azt is, hogy szerződésükben a Zugewinngemeinaschaft rendszerétől részben térjenek el, azt alakítsák, mint ahogy a vagyonközösség esetén is csak mintaként szolgál a törvényi szabályozás. Házassági vagyonjogi szerződést a felek együttesen, közjegyző előtt, közhiteles okiratba foglalva köthetnek (1410. §). Ezekből a rendelkezésekből egyételműen kitűnik, hogy a törvényes vagyonjog rendszere csupán szubszidiárius jellegű, azaz abban az esetben érvényesül, ha a felek szerződéssel nem rendzik vagyoni viszonyaikat a házasság fennállásának időtartamára. ${ }^{43}$

\subsection{Az 1976. évi családjogi reform}

Figyelemre méltó jelenség, hogy a GG 3. cikkelye 2. bekezdésében rögzített elv („a nők és férfiak egyenlöek”), valamint a család és házasság állami védelme (6. cikkely 1. bek.: „A házasság és a család az. államrend különös védelme alatt áll.'), ${ }^{44}$ sôt a nemi jogegyenlőségről szóló 1957. évi törvény ellenére is maradtak hiányosságok a polgári jogban a férfiak és nők egyenjogú helyzetét megteremtse tekintetében, és ezek a rendelkezések kevés tényleges pozitiv változást hoztak. A BGB 1356. \2. bekezdése 1977-ig érvényben maradt (,A nönek joga van keresötevékenységet folytatni, amennyiben ez. összeegyeztethetô a házassági és családi kötelęrettségeivel." ${ }^{\circledR 5}$ ), ami közvetett módon azt eredményezte, hogy a férj végső döntési joga a családi ügyekben (Stichendscheid), ${ }^{46}$ ha korlátozottan is, de megmaradt az 1356. $\$ 2. bekezdésére vonatkozó bírói gyakorlat keretében. ${ }^{47} \mathrm{Az}$ ez ellen benyújtott alkotmányjogi panaszok rámutatak arra, hogy reform inkább „makulatúra” volt, mint tényleges átalakítás. ${ }^{48} 1957$ es években hatálybalépett törvény nem tudott realizálni, vagy a jogalkalmazók, mint a Stichendscheid esetén egyszerúen nem alkalmazták a jogszabályváltozást.

Az 1960-as évek közepétől a német társadalom jelentős változáson ment át. Az Amerikai Egyesült Államokból érkező, a fennálló viszonyok elleni egyetemi hallgatói tiltakozás 1968 tavaszán a német egyetemeken is tetőfokára hágott, és a nőket is arra ösztönözte, hogy nyilvánosan kifejezzék társadalmi helyzetükkel kapcsolatos elégedetlenségüket. Az „új nôi mozgalom” követeléseit a lakosság széles rétegeiben megvitatták, ami ahhoz vezetett, hogy megkérdőjeleződött a társadalmi szerepmegosztások eddigi rendszere. Az ország újjáépítésének előrehaladását követően egyre szélesebb társadalmi réteg jutott erre a meggyőződésre, amiből politikai értelemben az SPD (Német Szociáldemokrata Párt) profitált. 1969 márciusában az SPD -nek sikerült elérnie, hogy szövetségi elnökjelöltje, Gustav Heinemann az FDP (Szabad Dememokraták) szavazataival többséget szerezzen a Szövetségi Gyúlésben, amivel köztársaságnak először lett szociáldemokrata államfője. A választási kampány során az SPD és kancellárjelöltje, Willy Brandt soha nem látott támogatást kapott.A lendületet nemcsak a politikai hatalom változásai adták, hanem a Szövetségi Alkotmánybíróság is, amelynek esetjoga idővel figyelemre méltó változásokon ment keresztül. ${ }^{49}$ Ennek köszönhetően, figyelemmel a társadalmi, politikai és jogi változásokrakra, az akkori szövetségi kormány egy

\footnotetext{
${ }^{43}$ Herger, A modern magyar házassági vagyonjog kialakulása és rendszere a német jogfejlődés tükrében $413-419$.

44 „Ehe und Familie stehen unter dem besonderen Schutze der staatlichen Ordnung.”

45 „Sie ist berechtigt, erwerbstätig zu sein, soweit dies mit ihren Pflichten in Ehe und Familie vereinbar ist.”

${ }^{46}$ SCHWAB, Familienrecht 286-289.

${ }^{47}$ SCHWAB, Familienrecht 288.

48 SCHWAB, Familienrecht 73-84.

${ }^{49}$ UngER-SOYKA, Das Ehe- und Familienleitbild der Sozialdemokratischen Partei Deutschlands 264-284.
} 
konventet állított fel, melynek feladata az volt, hogy az eddigi patriarchális BGB csaladjogi részét alapjaiban átalakítsa és egy jogszabály tervezetet dolgozzon ki ehhez. ${ }^{50}$

Miután az SPD belviszályokkal küzdött, több képviselő elhagyta a pártot, a kormányzáshoz szükséges többségüket elvesztették. A köztársasági elnök feloszlatta a szövetségi törvényhozó szervet és 1972-ben új választásokat tartottak. Ennek nyomán az 1969-ben elkezdődött reformtervezet kidolgozása valamint annak parlamenti vitája is háttérbe szorult. A konvent a munkáját csak 1973-ban folytatta. ${ }^{1}$

Az első családjogi reformtervezet (1973) atyjának is tekinthető Gerhard Jahn szövetségi igazságügyi miniszter a következőképpen fogalmazta meg az elképzelését: „Számos módositás dacára, amelyek végbementek az idök során, a mai napig a férfi egyoldalú elsöbbsége megmaradt (...) A törvényjavaslat célja, olyan házassági törvény létrehozása, amely a partnerségre alapuló házassági felfogásnak felel meg, továbbá egy igazságos bontóperi szabályozás és a bontóper követö igazságos jogkövetkezmények biztositása”. ${ }^{2}$ A törvény többszöri olvasat és parlamenti viták sorozatát köveően 1976. június 14-én lépett hatályba. ${ }^{53} \mathrm{~A}$ jogszabály az utolsó törvényjavaslattal összhangban a BGB családjogi könyvét öt területen változtatta meg alapjaiban, illetve egészítette ki azt. Az eddigi hiányosságokat Jahn a következőkben látta: „A hatályos házassági jogban és családjogban, különösen a bázasság személyi hatályának területén, a nöke jogainak egyenlösége még nem valósultak meg teljes mértékben. A bázassági bontójogban uralkodó vétkességi elvet alapjaiban elavultnak kell tekintenünk. A házasság, a házasság bontását és a házasság bontásából származó következményeinek joghatásait ezért új alapokera kell helyezni, amelyek a megváltozott társadalmi és gazdasági körülményeket figyelembe veszik és leképezilk. Az új anyagi jogi alapgondolatok szerint a házasság felbontásával kapcsolatos jogi hatásköröket és a házásság felbontásának következményeivel kapcsolatos intézkedéseket, azzal összefüggö itélkęési jogosultságokat üj birósági szervre kell átrubáznni. Családjogi kérdésekben ezentúl kĩárólag családjogi bíróságok dönthessenek. ${ }^{54}$

Megoldásként a javaslatban a következőket fogalmazták meg: „A házasságból származó személyes joghatások területén az, egyenlöség elve a bázastársak kö̈ötti partnerségi elv alapján valósul meg. A bontójogban a felróhatóság elvét a felduiltsági elv váltja fel. A házasság felbomlása vélelmezhetó, ha a házastársak három éve külön élnek; egy év különélés elegendö, ha mindkét házastárs a házasság felbontását kéri. Annake érdekében, hogy a felek a házasság felbontását rossz̧hiszemúen ne akadályozzák, vagy megnehezítsék, a bontást biztositó garanciarendszert kell kialakitani. A tartási kötelezettség rendezésénél a korábbi vétkességi elvet, amely gyakran igazságtalan eredményekhez vezetett, fel kell adni egy olyan szabályozás javára, amely a gazdaságilag gyengébb partner számára megfelelö bižtonságot nyüjt a megélhetési szü̈kégleteinek biztositása érdekében. A bázasság felbontása esetén a bázastársak által a házasságuk alatt szerzett nyugdijjogosultságra való várományosi jogállást szerzeményi vagyonként kell figyelembe venni. A törvényes nyugdíbiztositásban az elvált özvegyek nyugdijának tekintetében szintúgy változásokat kell eszközölni. A bázassági eljárásjogban a házassági ügyekre és a szorosan kapcsolódó eljárásokera vonatkozó hatáskörök egységesitése elkerüllhetetlen. A tervezet ęeket az ügyeket különleges biróságok

\footnotetext{
${ }^{50}$ UNGER-SOYKA, Das Ehe- und Familienleitbild der Sozialdemokratischen Partei Deutschlands 264-284.

${ }^{51}$ UNGER-SOYKA, Das Ehe- und Familienleitbild der Sozialdemokratischen Partei Deutschlands 264-284.

52 „Trotz. zablreicher Änderungen im Laufe der Zeit ist bis zum heutigen Tag waren einseitiger Vorrang des Mannes aufrechterbalten geblieben [...]. Ziel des Entwurfes ist ein Eherecht, das dem partnerschaftlichen Eheverständnis entspricht, ein faires und ehrliches Scheidungsrecht und ein gerechtes Scheidungsfolgenrecht. "Lásd BOROwSKY, Sozialliberale Koalition und innere Reformen 258.

${ }^{53}$ UnGER-SOYKA, Das Ehe- und Familienleitbild der Sozialdemokratischen Partei Deutschlands 278-282.

${ }^{54}$ JAHN, Bundesminister der Justiz - in der ersten Lesung des Entwurfs eines ersten Gesetzes zur Reform des Eheund Familienrechts, https://dserver.bundestag.de/btd/07/006/0700650.pdf.
} 
hatáskörébe utalja. A családjogi biróság gondolata igy megvalósul. Ha a felek a házasság felbontására irányuló eljárást és az alapeljáráshoz. kapcsolódó egyéb eljárásokat nem kölcsönös megálapodással indították meg, a határozatok egyidejü tárgyalása mellett (elméletileg) - a gyors és az összes kérdésben történó egyidejü batározathozatal érdekében - bevezetnék a döntéshozatal koncentrációjának az elvét. A közös megegyezéssel történó házasság felbontása esetén a házasság felbontásának kimondása attól függ, hogy a házastársak a házasság felbontásához. szüleséges lényeges kérdésekben egyességre jutnak-e, amely végrehajtható végzés vagy határozat meghozatalát lehetôvé teszi a biróságok számára. ${ }^{\top 55}$

Az 1976. július 1-jei reformtörvény körében a férj és a feleség közötti egyenjogúság biztosítása volt az első kulcskérdés. Ebbe a körbe tartozik többek között a házassági névhasználat szabályozása, a háztartás vezetésének kérdése, valamint a kulcshatalom, a munkavállalás szabadsága, a nő szerződéskötési szabadsága és felelősségvállalási joga.

A házassági névviselés szabályai a következőképp változtak a BGB 1355. \-ban: (1) A bázastársaknak közös családi nevet (bázassági nevet) kell viselniük. (2) A házasságkötéskor a házastársak az. anyakönyvvezetöhöz intézett nyilatkozattal a férfi születési nevét vagy a nö leánykori nevét jelölhetik meg házassági névként. Ha nem jelölnek meg semmit, a házassági név a férfi születési neve lesz. A születési/leánylkori név az a név, amelyet a jegyespár születési anyakönyvi kivonatában a bázasságkötés idöpontjában be lett jegyezve. (3) Aza házastárs, akinek születési/leánykori neve nem válik házassági családi névvé, az anyakönyvvezetôhöz intézett nyilatkozatával a leánykori/születéskori nevét vagy a házasságkötéskor használt nevét a házassági név elé belyezheti; a nyilatkozathoz nyillvános hitelesitésre van szüleség. (4) Az özvegy vagy elvált házastárs megtartja a házassági nevét. Az anyakönyvvezetöhöz. intézett nyilatkozattal felveheti leánykori/születéskori nevét vagy a házasságkötéskor viselt nevét; a nyilatkozatot nyilvánosan kell bitelesiteni. ${ }^{{ }^{56}}$ Bár a törvény fenntartotta a közös családi név intézményét, lehetőséget adott arra, hogy a felek döntsék el, melyik legyen ez a név. Megszünt az a gondolat, miszerint csak a férfi neve lehet a családi név. A névviselés jogának alakulása a reformtörvény hatályba lépését követően többször a politikai és tártsadalmi viták kereszttüzébe került, és az évtizedek során kiegészítések, módosítások sokasága követte. ${ }^{57}$

A férj és a feleség közötti egyenjogúság biztosítása érdekében a reformtörvény a házastársak közös döntési jogát és megegyezését helyezte elötérbe a férj végső döntô szavának (Stichendscheid) és a kulcshatalom intézményének (Schlüsselgewalt) az eltörlésével, ami a „gyengébb” nem előtt végleg megnyitotta a munkavállalás világat (1356. \1-2. bek.): „A házastársak közös megegyezéssel vezetik a

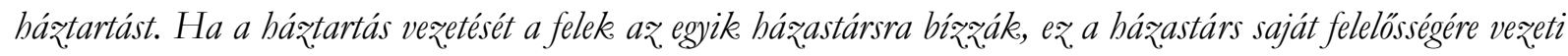
a háztartást. Mindkét házastárs jogosult keresôtevékenységet folytatni. A keresôtevékenység kiválasżtása és

\footnotetext{
${ }^{55}$ JAHN, Bundesminister der Justiz - in der ersten Lesung des Entwurfs eines ersten Gesetzes zur Reform des Eheund Familienrechts, https://dserver.bundestag.de/btd/07/006/0700650.pdf.

56 „(1) Die Ehegatten fübren einen gemeinsamen Familiennamen (Ehenamen). (2) [1] Zum Ehenamen können die Ehegatten bei der Eheschließung durch Erklärung gegenüber dem Standesbeamten den Geburtsnamen des Mannes oder den Geburtsnamen der Frau bestimmen. [2] Treffen sie keine Bestimmung, so ist Ehename der Geburtsname des Mannes. [3] Geburtsname ist der Name, der in die Geburtsurkunde der Verlobten zur Zeit der Eheschließung einzutragen ist. (3) Ein Ehegatte, dessen Geburtsname nicht Ehename wird, kann durch Erklärung gegenüber dem Standesbeamten dem Ehenamen seinen Geburtsnamen oder den zur Zeit der Eheschließung geführten Namen voranstellen; die Erklärung bedarf der öffentlichen Beglaubigung. (4) [1] Der verwitwete oder geschiedene Ehegatte behält den Ehenamen. [2] Er kann durch Erklärung gegenüber dem Standesbeamten seinen Geburtsnamen oder den Namen wieder annebmen, den er zur Zeit der Eheschließung gefübrt hat; die Erklärung bedarf der öffentlichen Beglaubigung."

${ }^{57}$ A házassági névviselés változásaihoz 1976 után lásd bővebben: UNGER-SOYKA, Das Ehe- und Familienleitbild der Sozialdemokratischen Partei Deutschlands 280-284.
} 
folytatása során kellöen figyelembe kell venniük a másik házastárs és a család érdekeit". ${ }^{58} \mathrm{Ez}$ a rendelkezés máig változatlanul hatályos, fontos azonban megjegyezni a tényt, hogy a munakerôpiac 1976 utáni kitágulása a nők számára nem hozta automatilusan magával a fizetések egyenlőségét. A gazdasági világban máig nagy diszharmónia figyelhető meg. ${ }^{59}$

A fontos változás volt a házastársak közötti jogegyenlőség tekintetébem a házas nő szerződéskötési és felelőségvállalási szabadságának biztosítása is (1357. \ 1-3. bek.): „Mindkét bázastárs jogosult a család szüleségleteinek ésszurü kielégitése érdekében a másik. házastársra is kiterjedó hatállyal ü₹letet kötni. Az ilyen ügyletek mindkét házastársat feljogositják és kötelerị, kivéve, ha a körülményekböl más követkerilk. A házastárs korlátozhatja vagy kizárbatja a másik házastársnak a másik házastársra vonatkozó, a saját nevében történó ügyintézési jogkörét; ha a korlátozásnak vagy kizárásnak nincs megfelelö oka, biróság kérelemre visszavonja ąt. A korlátozás vagy kizárás harmadik személyekekel szemben csak az. 1412. sqakasz. szerint hatályos. Az. (1) bekezdés nem alkalmazandó, ha a házastársak. külön élnek." ${ }^{60}$

A második kulcskérdésnek a reformtörvényben a házassági bontójog alapvető átalakítását és a családjogi bírósági rendszer kialakítását tekintették. A kánoni felbonthatatlanság elvétől - a de facto széttagolt német térség - már a 16. században elszakadt, amikor a protestáns felekezetek házassági jogában Martin Luther, illetve Jean Calvin teológiai nézeteit követve vétkességi elven alapuló, szubjektív bontójogi rendszert intézményesítettek. Ennek értelmében a házasságot akkor lehetett felbontani, ha az egyik házastárs vétkes magatartásával bontóokot valósított meg. A német egység létrejöttét (1871) követően a porosz, protestáns felekezeti jogon alapuló házassági törvényt alkalmazták a birodalomban, amely hozzájárult a 19. század utolsó évtizedeiben a német kultúrharc kibontakozásához. A BGB házassági köteléki jogában ilyen előzményekre támaszkodva megmaradt a vétkességi elv alkalmazása. ${ }^{61} \mathrm{Az}$ 1976. évi reform azonban a vétkességi elv helyett a feldúltság elvére (Zerrüttungsprinzip) helyezte a német bontójogot. A BGB 1566. szakaszának szövege a következőképp módosult: „(1) Megdönthetetlenül vélelmezni kell a házasság feldúltságát, ha a hárastársak egy éve külön élnek, és mindkét házastárs a házasság felbontását kéri, vagy az, alperes hozzájárul a házasság felbontásához: (2) Megdönthetetlenül vélelmezni kell a házasság felduiltságát, ha a házastársak három éve külön élnek." ${ }^{62}$ A feltúltság bizonyításához tehát a házastársak közös megyegyezése egy évi különélést szükséges, míg ennek hiányában, egyoldalú bontási szándék esetén háromévi különélés. A házasság

\footnotetext{
58 „(1) Die Ehegatten regeln die Haushaltsführung im gegenseitigen Einvernehmen. Ist die Haushaltsführung einem der Ehegatten überlassen, so leitet dieser den Haushalt in eigener Verantwortung. (2) Beide Ehegatten sind berechtigt, erwerbstätig zu sein. Bei der Wabl und Ausübung einer Erwerbstätigkeit haben sie auf die Belange des anderen Ehegatten und der Familie die gebotene Rücksicht zu nehmen." ${ }^{59}$ A Szövetségi Családügyi, Idősügyi, Nőügyi és Ifjúságügyi Minisztérium (Bundeministerium für Familie, Senioren, Frauen und Jugdend) adatai alapján Németországban a nők és férfiak közötti bérszakadék 19 százalék. Még azonos formális képzettség és egyébként azonos jellemzők mellett is hat százalékos a bérkülönbség. A nők rejtett hátrányos megkülönböztetésének egyértelmű jele a munkaerőpiacon.

${ }^{60}$ „(1) Jeder Ehegatte ist berechtigt, Geschäfte zur angemessenen Deckung des Lebensbedarfs der Familie mit Wirkung auch für den anderen Ehegatten zu besorgen. Durch solche Geschäfte werden beide Ehegatten berechtigt und verpflichtet, es sei denn, daß sich aus den Umständen etwas anderes ergibt. (2) Ein Ehegatte kann die Berechtigung des anderen Ehegatten, Geschäfte mit Wirkung für ibn zu besorgen, beschränken oder ausschließen; besteht für die Beschränkung oder Ausschließung kein ausreichender Grund, so hat das Vormundschaftsgericht sie auf Antrag aufžbeben. Dritten gegenüber wirkt die Beschränkung oder Ausschließung nur nach Maßgabe des $\int$ 1412. (3) Absatz 1 gilt nicht, wenn die Ehegatten getrennt leben."

${ }^{61}$ A házassági köteléki jog szekularizációjának folyamatáról és a BGB bontójogáról lásd HERGER, A nővételtől az állami anyakönyvvezetőig ..oldalszám.

62 „(1) Es wird unwiderlegbar vermutet, daß die Ehe gescheitert ist, wenn die Ehegatten seit einem Jabr getrennt leben und beide Ehegatten die Scheidung beantragen oder der Antragsgegner der Scheidung zustimmt. (2) Es wird unwiderlegbar vermutet, daß die Ehe gescheitert ist, wenn die Ehegatten seit drei Jahren getrennt leben."
} 
felbontásának radikális megkönnyítése kétségtelen, hogy hozzájárult a bontóperek számának rendkívüli növekedéséhez a reformtörvény hatálybalépését követően, ${ }^{63}$ a nyugati jogi kultúrában azonban ez a váltás teljesen elfogadott volt a 20. század második felében, a szovjetblokk országaiban - a szovjet családjogi modellt követve - pedig már a II. világháborút követően feladták a vétkességi elvú bontójogot. ${ }^{64}$

A reformtörvény harmadik kulcskérdése a házassági bontóper eljárási szabályai körében a hatáskör szabályozása volt. Szükségesnek mutatkozott egy olyan bíróságtípus felállítása, amely családjogi és azzal összefüggő ügyekben kizárólagos hatáskörrel rendelkezik. A reformtörvény hatálybalépését követően a jogalkotó módosította a bírósági törvény (Gerichtsverfssungsgesetz) 23. és 119. szakaszait, ${ }^{65}$ mellyel a járásbíróságokon belül létrehoztak egy speciális családjogi bíróságot, ezzel a nemzetközi kívánalmaknak is eleget téve. ${ }^{66}$

A negyedik kulcskérdés a házasság felbontása utáni tartási kötelezettség újraszabályozása volt. A reformtörvény hatályba lépése előtt a nemzetiszocialista rendszer szülötte, az 1938. július 6-i házassági törvény bontójoga érvényesült, melyen még Adolf Hitler aláíása szerepelt. ${ }^{67} \mathrm{~A}$ vétkességi elven alapuló bontójogból következően a vétkes felet terhelte a házasság felbontása után a tartási kötelezettség a vétlen fél javára, amennyiben az saját erejéből képtelen volt magáról gondoskodni. A reformtörvény a bontójogot visszahelyezte a BGB családjogába. ${ }^{68}$ A tartás kérdésében elvetette a családjogi felróhatóság elvét, és tartást a rászorultsághoz, a méltányossághoz és a szükségességhez kötötte: az 1569. S szerint „Ha a házastárs a házasság felbontását követöen nem tud saját magáról megfelelöen gondoskodni, jogosult a másik bázastárstól tartásra az alábbi rendelkezések szerint. " 69 A BGB a tartási igény négy típusát különíti el: a gyermekgondozás miatti tartás (1570. \$), az idős kor miati tartást (1571. §), a betegség vagy fogyatékosság miatti tartást (1572. 』) valamint a munkanélküliség miatti tartást illetve kiegészítő tartást (1573. §). A tartási jogosultságok mellé a jogalkotó egy „kötelességi klauzulát” is beemelt a jogszabályba, miszertint a tartásra jogosult köteles észszerű jövedelemszerzési magatartást tanusítani, arra törekedni, hogy képességeinek megfelelő munkavégzéssel, munka elfogadásával önellátóvá váljon (ún. megfelelő jövedelemszerző tevékenység, 1574. §).

A reformtörvény ötödik kulcskérdése az életejáradéki és nyugellátási járadékokból származó vagyon kigyenlítése volt a bontást követően (Versorgungsausgleich bei Scheidung). A reformtörvény a jogegyenlőség gondolatát vagyoni viszonyok tekintetében is továbbfejlesztette a szerzeményi közösség (Zugewinngesellschaft), mint törvényes vagyonjogi rendszer, illetve a szerzeményi kiegyenlítés (Zugewinnausgleich) szabályaiból kiindulva. A szerzeményi kiegyenlítést az úgynevezett ellátási kiegyenlítés (Versorgungsausgleich) egészítette ki. Az új intézmény az egyenlő vagyongyarapítás elvén alapulva a szerzeményi közösséget a várományi vagyon egészére, így különösen azokra a járandóságokra is kiterjesztette, melyek az időskori, egészségügyi romlás vagy egyéb okok

\footnotetext{
${ }^{63}$ SCHWAB, Familienrecht 292-294.

${ }^{64}$ Herger, A házasság felbonthatóságának megítélése 54-56.

${ }^{6} 5$ A bíróság szervezetéről szóló törvény, https://www.gesetze-im-internet.de/gvg/.

${ }^{66}$ SCHWAB, Familienrecht 296-297.

${ }^{67}$ Ehescheidungsrecht in der Fassung vom 06.07. 1938 - mely a gyermeki jogok kivételével 1977 július 01-ig lényegében érvényben maradt. https://www.jku.at/fileadmin/gruppen/142/Ehegesetz_1938.pdf

${ }^{68}$ BGB 4. könyv, 7. cím, 2. alcím 1569-1580. \$S.

${ }^{69}$ „Kann ein Ehegatte nach der Scheidung nicht selbst für seinen Unterhalt sorgen, so hat er gegen den anderen Ehegatten einen Anspruch auf Unterhalt nach den folgenden Vorschriften."
} 
bekövetkezése miatti keresőképtelenség esetére létesített juttatások körébe tartoznak, amennyiben ezek vagyoni biztosítékok a vagyonjogi rendszer fennállása idején jöttek létre (például az adott biztosítást ebben az időszakban kötötték és fizették annak díját). A tényleges változás abban mutatkozott, hogy az ellátási kiegyenlítés intézményén keresztül a szerzemények körébe már nem csak a magánautonómia alapján megkötött szerződésekből származó várományi vagyon került be (biztosítás, magánnyugdíj stb.), hanem a közjogon alapuló várományi vagyon is, mint az állami nyugdíj vagy a köztisztviselőknek járó juttatások. A kiegyenlítési eljárás a házasság felbontásakor azt jelenti, hogy az a házastárs, aki a házasság fennállása alatt csekélyebb mértékű ellátási pozícióba került, a másik házastárs terhére kiegyenlítésre tarthat igényt. A szerzeményi közösség alapelvéhez igazodóan az ellátási kiegyenlítés is kötelmi jogi igényt jelent, amit pénzfizetéssel, részesedés biztosításával vagy a felek által meghatározott más módon is kielégíthető. ${ }^{70}$ Miután a számítás és szabályozás 1976-ban túl bonyolultra sikeredet, a 2000-ben megkezdőtött az ellátási kiegyenlítés újraszabályozása úgy, hogy a BGB csak utal erre az intézményre (1587. §), és a részleteket külön törvény (Gesetz über den Versorgungsausgleich vom 01.09. 2009) tartalmazza.

\section{A családjogi reformok jelentősége és közvetett hatása}

Miután a 1960-as évek végén a német nômozgalom második hulláma új erőre kapott, megindult a női jogok társadalmi helyzetének és megítélésének javítását célzó folyamat, amely napjainkig sem zárult le. Ennek legnagyobb lendületet adó eleme az 1957. évi és az 1976. évi családjogi reform volt, amely visszahatott a nők társadalmi megitélésének alakulására is, illetve generálta más jogterületeken a jogegyenlőség hiányának a felszámolását. Ezek az eredmények megjelentek a büntetőjogban is, ahol a patria potestas maradványának tekintett úgynevezett női tűrési kötelezettséget 1997-ben felszámolták azzal, hogy a családon belüli erôszak tényállása bekerült a büntető kódexbe. 1976-ban megalapították az első női menedékotthont, melyet 2002-ig 450 ilyen intézmény felállítása követett, és ugyanekkor több férfi menedékszállót is létesítettek. A nőmozgalomnak köszönhetően a szövetségi, valamint a tagállami törvényhozó szervekbe egyaránt növekedésnek indult a női képviselők száma. Az, hogy napjainkban a képviselők harmada nő, hatalmas változás ahhoz képest, hogy 1919-ben nem érte el a 8\%-ot sem a női képviselők aránya, és a náci korszakban egyetlen női képviselő sem volt a törvényhozásban, amíg az egyáltalán működött. Jelentősége van annak is, hogy 2005 óta három alkalommal lett női kancellárja Németországnak, és az elmúlt másfél évtizedben több, a nők jogait védő, megalapozó és biztosító törvényi rendelkezés született, valamint 2007-ben a német kormány kidolgozott egy, a nők jogait és testi épségét biztosító hosszú távú kormányprogramot, amely 2015-ben a munkahelyi szexuális zaklatást tiltó szövetségi programmal folytatódott. ${ }^{71}$ Ezeknek a társadalmi és szemléletmódbeli változásoknak van egy visszahatása is a családjog területére: az emancipált nô képe kikezdhetetlen eleme a jogéletnek, ami természetesen lehetőséget, nem pedig kényszert jelent a nő számára, azaz koherens rendszert képez a nők családi életben feleségként és anyaként történő nemi szerepének a megbecsülésével.

\footnotetext{
${ }^{70}$ SCHWAB, Familienrecht 290-291.

${ }^{71}$ WiegemanN, Der Hürdenlauf der Frauen im Recht 28-43.
} 


\section{Felhasznált irodalom és források}

ABRAM, Helen: Ehegesundheit - Überblick über die Entwicklungen anhand der Gesetzgebung im „Dritten Reich“ und internationale Dimensionen. Díké 2019/2. sz. 3-18.

ALmA, Harry H.: Ein Vorschlag zur Eherechtsreform. Wien 1930

BEAUVOIR, Simone: A második nem. Budapest 1969

BETTELHEIM, Charles: Die deutsche Wirtschaft unter dem Nationalsozialismus. München 1974

BOLEMANT, Lilla - SZAPU, Marianna: Bevezetés a gendertanulmányokba. Pozsony - Nyitra 2015

BOROwSKY, P.: Sozialliberale Koalition und innere Reformen. Ehe- und Familienrecht. Informationen zur politischen Bildung, Heft 258. Bundeszentrale für Politische Bildung 2002

Di Croce, Genny: Historische Ereignisse-Online Zeitstrahl. Online Sammlung des Ministätriums füt Sozilaes und Integration, https://www.frauenwahlrecht-bw.de/damals-heute/zeitstrahl/ (Letöltés: 2021. 07. 23.)

DE GOUGES, Olympe: Declaration of the Rights of Woman and the Female Citizen, 1791. In: WARMEN, Caroline: Tolerance. The Beacon of the Enlightenment. 49-51. https://www.jstor.org/stable/pdf/j.ctt19b9jvh.24.pdf?refreqid=excelsior\%3Afcc090f270d8ce1151ba7bbed e32a37f (Letöltés: 2021. 07. 21.)

HELL, Judit: Egy testvér lesz minden ember - a nemek viszonya a globalizálódó világban. Magyar Tudomány 2002/3. sz. 322-332.

HellWIG, G.: Weg zur Gleichberechtigung. In: Bundeszentrale für politische Bildung: Frauen in Deutschland. Informationen zur politischen Bildung, 1997/254. sz.

HERGER Csabáné: A modern magyar házassági vagyonjog kialakulása és rendszere s német jogfejlődés tükrében. Passau 2017

HERGER Csabáné: Szakrális kontra szekuláris értékek a polgári modernizáció korában. Díké 2017/1. sz. 33-44.

HERGER Csabáné: A házasság felbonthatóságának megítélése. In: HerGER Csabáné - KATONÁNÉ PEHR Erika: Magyar családjog. Pécs 2021, 54-56.

JAHN, Gherhard: Bundesminister der Justiz. In der ersten Lesung des Entwurfs eines ersten Gesetzes zur Reform des Ehe- und Familienrechts, https://dserver.bundestag.de/btd/07/006/0700650.pdf

(Letöltés: 2021. 07. 30.)

JOHN, B. - STUTZER, E.: Erwerbsverhalten von Erziehungsurlauberinnen. Zeitschrift für Familienforschung 2002/3. sz. 215-233.

Jura Individuell: Die Entwiklung des Bürgerlichen Gesetzbuches. Online Fachzeitschrift, https://www.juraindividuell.de/artikel/die-entwicklung-des-buergerlichen-gesetzbuchs (Letöltés: 2021. 07. 24.)

KAJTÁR, István - HERGER Csabáné: Egyetemes állam és jogtörténet. Budapest 2015

KÉRI, Katalin: Tollam szivárványba mártom. Források az európai nőtörténet köréből az ókortól a 20. századig. Pécs 1999

LÉvY, Bernard-Henri: Sartre százada. Sartre és a nők: egy szerelem, akit Hódnak ívtak. Nagyvilág 2001/2. sz. 258-273.

LIMBACH, Jutta: Die Frauenbewegung und die Entstehung des Bürgerlichen Gesetzbuches. In: „Frauen und Rechte Landesweite Aktionswochen des Landes NRW. Reader der Fernuni-Hagen 2003, 43-54.

https://www.fernuni-hagen.de/rechtundgender/downloads/frauenundrecht.pdf (Letöltés: 2021.07.27)

MÜLleR-FreIENFELS, W.: The Marriage Law Reform of 1976 in the Federal Republic of Germany. International and Comparative Law Quarterly 1979/2. sz. 184-210.

NOTZ, Gisela: Frauen in der Mannschaft. Sozialdemokratinnen im Parlamentarischen Rat und im Deutschen Bundestag, 1948/49 bis 1957. Bonn 2003

STORM, Monika: 90 Jahre Frauenwahlrecht, Landeszentrale für Politische Bildung Reinland-Pfalz. https://www.politische-bildung.rlp.de/fileadmin/download_neu/Frauenwahlrecht.pdf

(Letöltés: 2021. 07. 23.) 
SCHULTZ, Ulrike: Ein Quasi-Stürmlein und Waschkörbe voller Eingaben: Die Geschichte von Art. 3 Abs. 2 Grundgesetz. In: „Frauen und Rechte - Landesweite Aktionswochen des Landes NRW. Reader der FernuniHagen 2003, 54-61.

https://www.fernuni-hagen.de/rechtundgender/downloads/frauenundrecht.pdf (Letöltés: 2021. 07. 27.)

SCHÜTTER, W. - SZABÓ, H.: A német családjog áttekintése. Acta Juridica et Politica 2013/2. sz. 217-269.

SCHWAB, DiETER: Familienrecht. München 2021, https://www.beckelibrary.de/10.17104/9783406731181277.pdf?download_full_pdf=1 (Letöltés: 2021. 07. 30.)

UNGER-SOYKA, Brigitte: Das Ehe- und Familienleitbild der Sozialdemokratischen Partei Deutschlands. Berlin 2009

v. MüNCH, Eva-Maria: Hausfrauen-Ehe abgechafft. Die Zeit Online (15. 10. 1979) https://www.zeit.de/1976/43/hausfrauen-ehe-abgeschafft/komplettansicht (Letöltés: 2021. 07. 27.)

ZETKIN, Clara: Abschied von der Gleichheit. Leipziger Volkszeitung, 19. Juni 1917. In: ZETKIN, Clara: Ausgewählte Reden und Schriften I. Berlin 1957, 759-765. https://www.marxists.org/deutsch/archiv/zetkin/1917/06/abschied.htm (Letöltés: 2021. 07. 23.)

ZETKIN, Clara: Lenin on the Women's Question. In: ZETKIN, Clara: My memorandum Book, https://www.marxists.org/archive/zetkin/1920/lenin/zetkin1.htm (Letöltés: 2021. 07.)

WICKERT, Christl - STÖCKER, Helene: Frauenrechtlerin und Pazifistin. Eine Biographie. Bonn 1991

WiegemanN, Barbelies: Der Hürdenlauf der Frauen im Recht seit 1900. In: „Frauen und Rechte - Landesweite Aktionswochen des Landes NRW. Reader der Fernuni-Hagen 2003, 28-43. https://www.fernuni-hagen.de/rechtundgender/downloads/frauenundrecht.pdf (Letöltés: 2021. 07. 27.)

Bericht über die 430, Sitzung des Bundesrates (30. 01. 1976). Zur Abstimmung über das „Erstes Gesetz zur Reform des Ehe- und Familienrechts“ (1.EheRG)

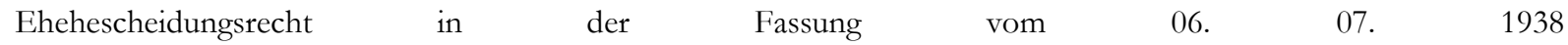
https://www.jku.at/fileadmin/gruppen/142/Ehegesetz_1938.pdf. (Letöltés: 2021. 07. 30.)

Erstes Gesetz des Ehe- und Familienrechts http://www.gesetze-im-internet.de/eherg_1/index.htm (Letöltés: 2021. 07. 24.)

Gesetz über die Gleichberechtigung von Mann und Frau auf dem Gebiet des bürgerlichen Rechts vom 18. 06. 1957 https://www.bgbl.de/xaver/bgbl/start.xav?start=\%2F\%2F*05B\%40attr_id\%3D \%27bgbl157026.pdf $\% 27$ $\% 5 \mathrm{D} \#$ _bgbl_\%2F\%2F*0\%5B\%40attr_id $\% 3 \mathrm{D} \% 27 \mathrm{bgbl157026.pdf} \% 27 \% 5 \mathrm{D} \_1627230758258$ (Letöltés: 2021. 07. 24.)

Gesetz über den Versorgungsausgleich vom 01. 09. 2009, https://www.gesetze-iminternet.de/versausglg/VersAusglG.pdf (Letöltés: 2021. 07. 30.)

Grundgesetz Art. 3 Abs. 2 in der Fassung von 1949 https://lexetius.com/GG/3,2 (Letöltés: 2021. 07. 27.)

Grundgesetz Art. 6 Abs. 1 in der Fassung von 1949 https://lexetius.com/GG/6, (Letöltés: 2021. 07. 24.)

Grundgesetz nach der Fassung vom 14. 12. 1976 https://www.gesetze-im-internet.de/gg/BJNR000010949.html (Letöltés: 2021. 07. 24.)

Stellungnahme der Bundesrates: Entwurf eines Gesetzes über die Gleichberechtigung von Mann und Frau auf dem Gebiete des bürgerlichen Rechts (2. Whalperiode 1953 am 29. Januar 1954 / Drucksache 224) https://dserver.bundestag.de/btd/02/002/0200224.pdf (Letöltés: 2021. 07. 31.) 